\title{
Analysis of Tariff Integration Between MRT and TransJakarta*
}

\author{
Kevin Ginevra Arota Hulu \\ Civil Engineering Department \\ University of Indonesia \\ Depok, Indonesia \\ kevin.hulu@yahoo.co.id
}

\author{
Andyka Kusuma \\ Civil Engineering Department \\ University of Indonesia \\ Depok, Indonesia \\ andyka.k@eng.ui.ac.id
}

\begin{abstract}
The Tariff Integration System is a tariff payment system where users of public transportation make payments only once but can use two or more modes of public transportation. For this study, the modes of transportation reviewed are TransJakarta and MRT. The purpose of this study is to find out the preferences that affect the community regarding tariff integration, to know the factors that can influence people's behaviour towards tariff integration, as well as the preference for integration rates for the community. The data collection method for this study is the Stated Preference Method. The survey conducted in two places, namely in the downtown and in the suburbs. The survey in the downtown is held at the Bendungan Hilir Shelter (TransJakarta Corridor 1) while the survey in the suburbs is carried out at Lebak Bulus Station. Data processing methods for this study is the Discrete Choice Model. The two influential variables in this study are price and time. The results of this study are the number of tariffs that can be accepted by the community.
\end{abstract}

Keywords: Tariff Integration System, TransJakarta, MRT, Stated Preference Method, Discrete Choice Model

\section{INTRODUCTION}

DKI Jakarta Province is the most populous province in Indonesia. The population of DKI Jakarta increases every year, according to population projections in 2010, the population of DKI Jakarta in 2018 will be 10.46 million people with a population density of 15.804 people $/ \mathrm{km}^{2}$ [1]. Along with the increase in the population of the city of Jakarta, motorised vehicle users in Jakarta also experienced an increase where the number of motorised vehicles in 2016 according to the Jakarta Central Bureau of Statistics amounted to 18.006 .404 million vehicles [2]. This increase causes congestion that can affect economic and social activities in the city of Jakarta.

Therefore, the government made several ways to overcome the congestion problem, one of which is to provide alternative transportation that serves to reduce the use of private vehicles this two alternatives public transportation namely TransJakarta and MRT. Jakarta's population expenditures for public transportation according to Iskandar Abubakar, Chair of the Jakarta City Transportation Board, the average Jakarta citizen is spending 20 to 30 per cent of his income to use public transportation which should be a maximum of 14 per cent of total income [3].

Therefore, tariff integration is beneficial for Jakarta

This study is funded through the PITTA grant scheme No. ND 162/UN2.R3.1/PPM.00/2019 residents to reduce transportation cost. Tariff integration allows passengers to use several transportation modalities by only buying one ticket, which can be used for a short period or can also have seasonal validity [4]. Therefore, this study tries to find out what the people of Jakarta perceive about the tariff integration system.

\section{TARIFF INTEGRATION SYSTEM}

The Integration Tariff system allows passengers to use several transportation modalities (for example, intercity and city buses, subways, local trains, and ferries). By only buying one ticket, which can be used in a short period (for example, two hours, everyday ticket) or it can also have seasonal validity (for example, weekly, monthly or yearly). Thus, integrated travel cards allow users to consider the entire public transport system in a particular area (urban, metropolitan or even regional) as if a single company offering unitary services organized it. The Integration Tariff System has been introduced in many countries (London, Stockholm, and Italy) and is the subject of exploratory studies promoted by the European Commission, and by Governments [4].

TABLE I. TARIFF TYPES

\begin{tabular}{|c|c|c|c|}
\hline \multicolumn{4}{|c|}{ Advantages and Disadvantages of Main Tariff Types } \\
\hline $\begin{array}{l}\text { Main } \\
\text { Types }\end{array}$ & $\begin{array}{l}\text { Important to } \\
\text { Consider }\end{array}$ & Advantages & Disadvantages \\
\hline $\begin{array}{l}\text { Zone tariff } \\
\text { (ring zone, } \\
\text { area zone, } \\
\text { honeycomb) }\end{array}$ & 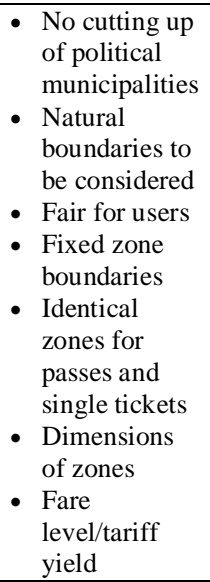 & $\begin{array}{l}\text { - Transparenc } \\
\text { y and } \\
\text { simplicity } \\
\text { - Customer } \\
\text { orientation } \\
\text { - Large zones } \\
\text { - Easy } \\
\text { handling for } \\
\text { operators }\end{array}$ & $\begin{array}{l}\text { - Low tariff } \\
\text { yield, } \\
\text { depending } \\
\text { on tariff sub- } \\
\text { type } \\
\text { - Possible } \\
\text { large price } \\
\text { jumps at } \\
\text { zone } \\
\text { boundaries; } \\
\text { tariff } \\
\text { regulations } \\
\text { for } \\
\text { mitigations } \\
\text { leads to } \\
\text { unwanted } \\
\text { complexity }\end{array}$ \\
\hline $\begin{array}{l}\text { Kilometre } \\
\text { tariff }\end{array}$ & $\begin{array}{l}\text { - Fair for users } \\
\text { - Transparent } \\
\text { for users } \\
\text { - Fare } \\
\text { level/tariff } \\
\text { yield } \\
\end{array}$ & $\begin{array}{l}\text { Easy } \\
\text { handling for } \\
\text { operators } \\
\text { - High tariff } \\
\text { yield }\end{array}$ & $\begin{array}{l}\text { Transparenc } \\
\text { y for users }\end{array}$ \\
\hline
\end{tabular}


Different types of tariff systems exist throughout Europe, each with its advantages and disadvantages. Most systems based on zone rates or kilometer rates. It is essential to verify which type of tariff is suitable for a particular area [5]. As can be seen in TABLE I.

Some of the benefits of price integration come from reducing transaction costs for passengers. Interchanges are easier to exploit, and boarding time is reduced because some controls can be issued to passengers who have validated their documents beforehand. Price integration tends to reduce the quality gap between public and private (automobile) transportation, by increasing flexibility from the previous one in meeting customer demand, and thus is credited with expanding the protection of public transport [6].

\section{MRT AND TRANSJAKARTA NETWORK}

TABLE II. MRT AND TRANSJAKARTA NETWORK MAP

\begin{tabular}{|c|c|c|c|c|}
\hline \multirow{20}{*}{$\begin{array}{l}\text { Transjakarta } \\
\text { (Corridor 1) } \\
\text { Shelter }\end{array}$} & Blok M & $\begin{array}{l}\text { Lebak } \\
\text { Bulus }\end{array}$ & \multirow{13}{*}{$\begin{array}{c}\text { Phase } \\
1\end{array}$} & \multirow{20}{*}{$\begin{array}{l}\text { MRT } \\
\text { Stations }\end{array}$} \\
\hline & $\begin{array}{l}\text { Agung } \\
\text { Mosque }\end{array}$ & Fatmawati & & \\
\hline & $\begin{array}{l}\text { Senayan } \\
\text { Roundabout }\end{array}$ & $\begin{array}{l}\text { Cipete } \\
\text { Raya }\end{array}$ & & \\
\hline & \multirow{2}{*}{$\begin{array}{l}\text { Gelora } \\
\text { Bung } \\
\text { Karno } \\
\end{array}$} & Haji Nawi & & \\
\hline & & Blok A & & \\
\hline & $\begin{array}{l}\text { Polda } \\
\text { Metro Jaya }\end{array}$ & Blok M & & \\
\hline & Benhil & ASEAN & & \\
\hline & $\begin{array}{l}\text { Karet } \\
\text { Sudirman }\end{array}$ & Senayan & & \\
\hline & $\begin{array}{l}\text { Dukuh Atas } \\
1\end{array}$ & Istora & & \\
\hline & Tosari & Setiabudi & & \\
\hline & $\begin{array}{l}\text { HI } \\
\text { Roundabout }\end{array}$ & Benhil & & \\
\hline & Sarinah & $\begin{array}{l}\text { Dukuh } \\
\text { Atas }\end{array}$ & & \\
\hline & $\mathrm{BI}$ & Bund.HI & & \\
\hline & Monas & Sarinah & & \\
\hline & $\begin{array}{l}\text { Harmoni } \\
\text { Central }\end{array}$ & Monas & & \\
\hline & $\begin{array}{l}\text { Sawah } \\
\text { Besar }\end{array}$ & Harmoni & & \\
\hline & $\begin{array}{l}\text { Mangga } \\
\text { Besar }\end{array}$ & $\begin{array}{l}\text { Sawah } \\
\text { Besar }\end{array}$ & $\begin{array}{c}\text { Phase } \\
2\end{array}$ & \\
\hline & Olimo & $\begin{array}{l}\text { Mangga } \\
\text { Besar }\end{array}$ & & \\
\hline & Glodok & Glodok & & \\
\hline & City & City & & \\
\hline
\end{tabular}

Based on the map of the TransJakarta Network [7] and the MRT network map [8], we can conclude that there are several intersections between the TransJakarta Corridor 1 and the MRT station. As can be seen in TABLE II. above, this integration will occur at Lebak Bulus Station, Blok M Station, ASEAN Station, Istora Station, Senayan Station, Bendungan Hilir Station, Dukuh Atas Station, and Hotel Indonesia Station Roundabout [9]. Those stations are where the tariff integration system will be carried out. This paper took samples in TransJakarta Corridor 1, precisely at Bendungan Hilir Shelter and MRT Station at Lebak Bulus
Station. This place was chosen because the potential market for MRT mostly comes from TransJakarta Corridor 1 and Lebak Bulus Station, also to see MRT users from downtown and suburbs.

\section{Discrete Choice Model And Stated Preference METHOD}

In seeking tariff integration, this paper approaches the method using the discrete choice model. The Discrete Choice Model can be used to analyze and predict decisionmakers from one alternative from a series of exclusive alternatives and limited complementarity. Such a model has many applications because many behavioral responses are discrete or qualitative; that is, they are following the choice of one or another of a series of alternatives [10].

The binary logit model is used to do modal selection modelling, which consists of only two alternative modes. There are two types of models that are often used, namely the logit-binary-difference model and the logit-binary-ratio model that can be solved using linear regression-based methods. The quantitative parameters that are often used as determinants in modal choice are travel costs or travel time. The choice between the logit-binary-difference model and the logit-binary ratio model in the choice of mode is primarily determined by one's perception of comparing travel costs or travel time in choosing the mode to be used. If the travel time data between zone pairs varies greatly, it is better to use the logit-binary ratio model, whereas if travel time is not very varied, it can use the logit-binary-difference model [11].

For two alternative modes, the probability of choosing a mode I can be calculated by the following probability: [11]

$$
P t(i)=\exp \{-\beta(V i t)\} /[\exp \{-\beta(V i t)\}+\exp \{-\beta(V j t)\}]
$$

For the equation of the logit-binomial are [11]:

$$
Z_{i}=\beta_{0}^{i}+\beta_{1}^{i} X_{1}^{i}+\beta_{2}^{i} X_{2}^{i}+\cdots+\beta_{K}^{i} X_{K}^{i}
$$

The use of stated preference methods to search for data is used because this method allows controlling the choices that will be given to a hypothetical situation, then these choices will be given to the respondent so that we know each respondent's preferences. So stated preference conditions meet the needs of the discrete choice model. Stated Preference Method refers to a part of a technique that uses individual respondents' statements about preferences in a set of transportation options to estimate utility functions. The choice is usually a description of the transportation situation or the context that was built by the researcher. By their nature, stated preference methods require surveys specifically designed for data collection [12]. The variables that we use on stated preference method are known in the previous discussion, namely time and cost.

\section{DESCRIPTIVE RESPONDENT}

In the Downtown survey conducted at the Bendungan Hilir Shelter (TransJakarta Corridor 1), there were 55 
respondents. The respondents consisted of 27 men and 28 women. Of the 55 respondents, there were seven respondents aged under 20 years, 31 respondents aged 20 - 39 years, and 17 respondents aged 40 - 59 years. The work of the respondents consisted of 8 students, PNS / TNI / POLRI totalling two respondents, entrepreneurs/traders totalling seven respondents, private employees totalling 28 respondents, and the other ten respondents. Income of respondents in a month varies significantly with an average income of Rp8.000.000 - Rp10.000.000 In the suburban survey conducted at Lebak Bulus Station, there were 70 respondents. The respondents consisted of 26 men and 44 women. Of the 70 respondents, there were five respondents aged under 20 years, 52 respondents aged 20 - 39 years, and 13 respondents aged 40 - 59 years. The work of the respondents consisted of students totalling eight respondents, PNS / TNI / POLRI totalling two respondents, entrepreneurs/traders totalling four respondents, private employees totalling 50 respondents, and the other amounting to 6 respondents. The income of respondents in a month varies significantly with an average income of Rp8.000.000 Rp10.000.000.

\section{DATA ANALYSIS}

\section{A. The Downtown}

Data processing for 55 respondents can use the $\mathrm{R}$ program to get the beta value of each variable. The variables included time savings, the difference between TransJakarta waiting time and MRT transfer time, additional MRT rates, gender, and frequency of TransJakarta usage. So that the utility equation is obtained as follows:

$\mathrm{U}_{\mathrm{MRT}}=6.217+0.05185 \mathrm{SAV}_{\mathrm{TIME}}-0.02551 \mathrm{SELISIH}$ $0.0005020 A D D \_T A R I F F \_M R T-0.5791$ GENDER 0.04858 FREQ

Based on (1), probability values can search using the formula:

$$
\begin{gathered}
P(i)=\exp (U i) /[\exp (U i+U j)] \\
P(i)=1-P j=1 /[1+\exp (U i-U j)]
\end{gathered}
$$

After getting the probability value using equation (5), the writer can determine the value of WTP based on the probability of 0.5 or close to 0.5 . WTP values are at the probability of selection at $\mathrm{P}=0.5$, indicating that the market share is expected to be balanced [11]. From the data processing, it was found that the value of WTP, were for men wanted the value of the WTP was Rp13.000 while the woman wanted the value of the WTP was Rp11.000.

\section{B. The Suburbs}

Data processing for 70 respondents can use the $\mathrm{R}$ program to get the beta value of each variable. Data processing is done three times. The variables included are time savings, additional MRT rates, and gender. In the second and third processing, the variables entered remained the same as the first processing but were divided according to the length of the travel group, where the group I with the duration of travel $<=60$ minutes and group II with a travel time $>60$ minutes.

From the results of $\mathrm{R}$ processing, the first utility equation can be known as follows:

$\mathrm{U}_{\mathrm{MRT}}=3.784+0.009095 \mathrm{SAV}_{\mathrm{TIME}}-$

0.0002970ADD_TARIFF_MRT -0.3943 GENDER

From the results of processing R, Group I, we can find the utility equation as follows:

$\mathrm{U}_{\mathrm{MRT}}=4.405+0.008210 \mathrm{SAV}_{\mathrm{TIME}}-$

0.0003126ADD_TARIFF_MRT -0.9258 GENDER

From the results of processing R, Group II, we can find the utility equation as follows:

$\mathrm{U}_{\mathrm{MRT}}=3.117+0.01085 \mathrm{SAV}_{\mathrm{TIME}}-$

0.0002869ADD_TARIFF_MRT + 0.3070GENDER

From the first data processing, it was found that the WTP value was Rp13.500 for men while the women had a WTP value of $\mathrm{Rp} 12.500$. Whereas for the other data processing the value of the WTPs is different for both sexes, where for men, the value of the WTPs is Rp15.000 while for women, the WTP value is Rp12.500. For the third data processing, it was found that the value of the WTP was Rp12.000 for men while the women had the value of WTPs of Rp13.000.

\section{Perception of Respondents}

In conducting data retrieval, the paper includes questions related to the perceptions of respondents in paying additional rates and paying transportation fares in a day. As can be seen in TABLE III.

\begin{tabular}{|c|c|}
\hline \multicolumn{2}{|c|}{ Perception of Respondents (The Downtown } \\
\hline \multicolumn{2}{|c|}{ Additional Tariff } \\
\hline Price & Respondents \\
\hline$<=\mathrm{Rp} 14.000$ & 32 \\
\hline$>$ Rp14.000 & 23 \\
\hline \multicolumn{2}{|c|}{ Transportation Expenses in a Day } \\
\hline$<=\mathrm{Rp} 20.000$ & 24 \\
\hline$>$ Rp20.000 & 31 \\
\hline \multicolumn{2}{|c|}{ Perception of Respondents (The Suburban) } \\
\hline \multicolumn{2}{|c|}{ Additional Tariff } \\
\hline Price & Respondents \\
\hline$<=\mathrm{Rp} 14.000$ & 51 \\
\hline$>\mathrm{Rp} 14.000$ & 19 \\
\hline \multicolumn{2}{|c|}{ Transportation Expenses in a Day } \\
\hline$<=\mathrm{Rp} 20.000$ & 20 \\
\hline$>\mathrm{Rp} 20.000$ & 50 \\
\hline
\end{tabular}

TABLE III. PERCEPTION OF RESPONDENTS

For the downtown, this paper searched for the average value for additional tariffs and daily transportation expenses from the 55 respondents. The result is for an additional yield of Rp12.000 and transportation expenses in a day; the result is $\mathrm{Rp} 27.000$. For the suburbs, this paper looks for the 
average value for additional tariffs and transportation expenses in a day from 70 respondents. The result is an additional tariff of Rp10.500, and for transportation expenses in a day, the result is $\operatorname{Rp} 32.500$.

\section{Zone Tariff}

After obtaining WTP values and perceptions of respondents from the city centre and suburbs, data processing conducted by combining between downtown and suburban respondents to get the desired rate. The desired tariff is based on the zone. This paper divides Jakarta by 4 zones where zone 1 has a radius of $5 \mathrm{~km}$, zone 2 has a radius of $10 \mathrm{~km}$, zone 3 has a radius of $15 \mathrm{~km}$, and zone 4 has a radius of $20 \mathrm{~km}$. The midpoint of the four zones is the Monumen Nasional (Monas). This paper then divides the respondent based on the zone where the respondent starts travelling and the zone where the respondent ends the trip. As can be seen in Fig. 1 below.

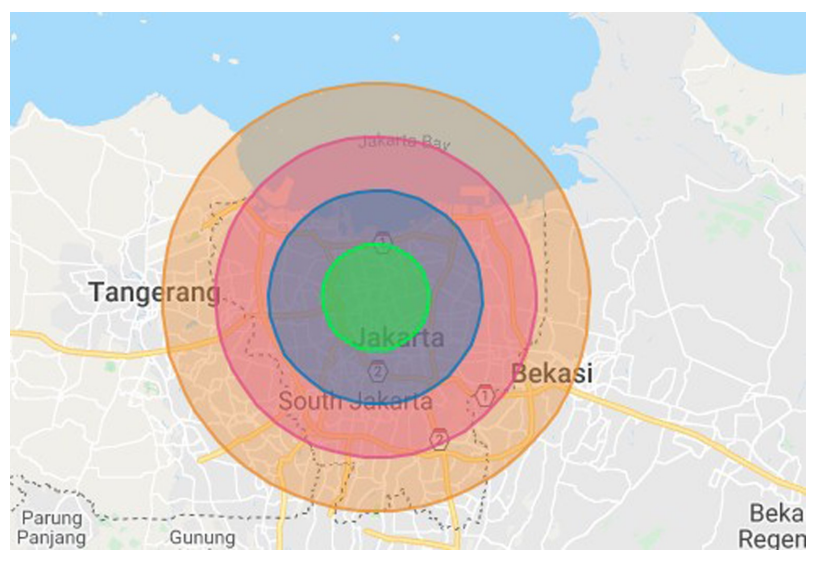

Fig. 1. Zone Division.

TABLE IV. WTP VALUe BetweEn Zones

\begin{tabular}{|c|c|c|c|}
\hline \multicolumn{4}{|c|}{ Willingness To Pay } \\
\hline Trip & Distance & Tariff & Tariff $(/ \mathbf{k m})$ \\
\hline Zone 1-1 & $10 \mathrm{~km}$ & $\mathrm{Rp} 12.500$ & $\mathrm{Rp} 1.250 / \mathrm{km}$ \\
\hline Zone 1-2 & $15 \mathrm{~km}$ & Rp 12.750 & $\operatorname{Rp} 850 / \mathrm{km}$ \\
\hline Zone 1-2 & $20 \mathrm{~km}$ & Rp 13.000 & $\mathrm{Rp} 650 / \mathrm{km}$ \\
\hline Zone 1-4 & $25 \mathrm{~km}$ & Rp 13.750 & $\operatorname{Rp} 550 / \mathrm{km}$ \\
\hline Zone 2-1 & $15 \mathrm{~km}$ & $\mathrm{Rp} 12.750$ & $\mathrm{Rp} \mathrm{850/km}$ \\
\hline Zone 2-2 & $20 \mathrm{~km}$ & Rp 13.000 & $\mathrm{Rp} 650 / \mathrm{km}$ \\
\hline Zone 2-3 & $25 \mathrm{~km}$ & $\mathrm{Rp} 13.750$ & $\mathrm{Rp} 550 / \mathrm{km}$ \\
\hline Zone 2-4 & $30 \mathrm{~km}$ & $\mathrm{Rp} 13.500$ & $\mathrm{Rp} 450 / \mathrm{km}$ \\
\hline Zone 3-1 & $20 \mathrm{~km}$ & Rp 13.000 & $\mathrm{Rp} 650 / \mathrm{km}$ \\
\hline Zone 3-2 & $25 \mathrm{~km}$ & $\mathrm{Rp} 13.750$ & $\mathrm{Rp} 550 / \mathrm{km}$ \\
\hline Zone 3-2 & $30 \mathrm{~km}$ & $\mathrm{Rp} 13.500$ & $\mathrm{Rp} 450 / \mathrm{km}$ \\
\hline Zone 3-4 & $35 \mathrm{~km}$ & Rp 14.000 & $\mathrm{Rp} 400 / \mathrm{km}$ \\
\hline Zone 4-1 & $25 \mathrm{~km}$ & Rp 13.750 & Rp 550/km \\
\hline Zone 4-2 & $30 \mathrm{~km}$ & Rp 13.500 & $\mathrm{Rp} 450 / \mathrm{km}$ \\
\hline Zone 4-3 & $35 \mathrm{~km}$ & Rp 14.000 & Rp 400/km \\
\hline Zone 4-4 & $40 \mathrm{~km}$ & Rp 14.000 & Rp 350/km \\
\hline
\end{tabular}

Processing data on 125 respondents can use the $\mathrm{R}$ program to get the beta value of each variable. Variables included sex, saving time, additional MRT rates, the origin of travel, and end of the trip. So that the utility equation is obtained as follows:

$$
\begin{aligned}
& \mathrm{U}_{\mathrm{MRT}}=4.6595830-0.5283956 \mathrm{GENDER}+ \\
& 0.0079363 \mathrm{SAV}_{\mathrm{TIME}}-0.00033770 \mathrm{ADD} \text { TARIFF_MRT }- \\
& 0.0292238 \mathrm{ORIG}+0.1844504 \mathrm{DESTI}
\end{aligned}
$$

From data processing, it was found that the value of WTP can be seen listed in TABLE IV.

\section{E. Data Comparison}

In the downtown, the WTP value is obtained based on R data processing by averaging the WTP value of all data processing which is Rp12.000. Based on the question of the respondent's perceptions, it was also found that the WTP value was Rp12.000. It can be concluded that the results of processing R data and WTP values are appropriate. In the suburbs, the WTP value is obtained based on R data processing by averaging the WTP value of all data processing which is Rp13.000. Based on the question, the respondent's perceptions were also obtained from the WTP value of Rp10.500. It can be concluded that the results of processing R data and WTP values are not identic. These results happen because even though the respondent is willing to pay a higher price, the respondent still wants a lower price. The value between the two prices is $\mathrm{Rp} 12.000$.

If the additional tariff applied is Rp.10,500, there will be an increase in the probability of passengers from the downtown by 0,20 . Whereas for passengers from the suburbs there is a probability increase of 0.23 . If the additional tariff applied is Rp12.000, there is no addition or reduction in the probability of passengers from the downtown. Whereas for passengers from the suburbs, there is an increase in the probability of passengers by 0.06 . If the additional tariff applied is Rp13.000, there will be a reduction in the probability of passengers from the downtown by 0.09 . Whereas for passengers from the suburbs, there is no addition or reduction in the probability of passengers. As can be seen in TABLE V.

TABLE V. Probability OF PASSANGERS

\begin{tabular}{|l|l|l|}
\hline \multirow{2}{*}{$\begin{array}{c}\text { Additional } \\
\text { Tariff }\end{array}$} & \multicolumn{2}{c|}{ Probability of Passengers } \\
\cline { 2 - 3 } & \multicolumn{1}{|c|}{ Downtown } & \multicolumn{1}{c|}{ Suburban } \\
\hline Rp10.500 & $(+) 0,2$ & $(+) 0,23$ \\
\hline Rp12.000 & 0 & $(+) 0,06$ \\
\hline Rp13.000 & $(-) 0,09$ & 0 \\
\hline
\end{tabular}

If the zone tariff is applied, then the additional tariff for one trip in one zone is Rp12.500, two zones are Rp13.000, three zones is Rp13.500, and four zones is Rp13.750. With the additional TransJakarta tariff of Rp3.500 and an estimated additional online transportation tariff of Rp10.000, the travel tariff for one trip in one zone is Rp26.000, 2 zones are Rp26.500, 3 zones is Rp27.000, and 4 zones is Rp27.250. If the respondent travels twice a day for a month (25 working days) then the respondent's transportation expenditure for a month, if the average income of the respondent for a month is Rp9.000.000, will be between $14 \%$ - $15 \%$ of the respondent's income per 
month. However, if the respondent's income is based on the UMR of the city of Jakarta, which is Rp3.940.973,096 [13], the price of the tariff is above $33 \%-35 \%$ of income. Therefore, government subsidies are needed to help respondents who have income at the UMR. As can be seen in TABLE VI.

TABLE VI. The Percentage of Transportation ExPENSES PER MONTH FROM MONTHLY INCOME

\begin{tabular}{|l|l|l|}
\hline $\begin{array}{c}\text { Transportation } \\
\text { Expenditure }\end{array}$ & Income & Percentage \\
\hline $\mathrm{Rp} 1.300 .000$ & \multirow{4}{*}{$\mathrm{Rp} 9.000 .000$} & $14 \%$ \\
\cline { 1 - 1 } $\mathrm{Rp} 1.325 .000$ & & $14,7 \%$ \\
\cline { 1 - 1 } $\mathrm{Rp} 1.350 .000$ & & $15 \%$ \\
\hline $\mathrm{Rp} 1.362 .500$ & & $15,1 \%$ \\
\hline $\mathrm{Rp} 1.300 .000$ & \multirow{2}{*}{$\mathrm{R} 3.940 .973,096$} & $33,6 \%$ \\
\hline $\mathrm{Rp} 1.325 .000$ & & $34,3 \%$ \\
\hline $\mathrm{Rp} 1.350 .000$ & & $35 \%$ \\
\hline $\mathrm{Rp} 1.362 .500$ & & $33,0 \%$ \\
& &
\end{tabular}

\section{DATA ANALYSIS}

- The survey was conducted at Bendungan Hilir Shelter (TransJakarta Corridor 1) and Lebak Bulus Station. This survey was conducted to see the probability and value of the WTPs of city and suburban passengers.

- Time savings, additional rates, and gender affect the value of WTP.

- Transportation expenses for the suburbs in a day are higher than the transportation expenses for the downtown in a day.

- The price of tariff integration greatly influences the probability of city and suburban passengers to use the MRT and TransJakarta.

- If the respondent's income is Rp 9.000.000, then the respondent's expenditure for public transportation if the tariff integration applies between MRT and TransJakarta is $14 \%-15 \%$ of the respondent's income a month. If the respondent's income is at the UMR, Rp3.940.973,06, then the respondent's expenditure for public transportation if the tariff integration applies between MRT and TransJakarta is $33 \%-35 \%$ of the respondent's income a month. Therefore, government subsidies are needed to help respondents who have income at the UMR.

\section{ACKNOWLEDGMENT}

We want to give our high appreciation for Universitas Indonesia for providing an opportunity in studying tariff integration between MRT and TransJakarta. This study is funded through the PITTA grant scheme No. ND162/UN2.R3.1/PPM.00/2019.

\section{REFERENCES}

[1] Central Bureau of Statistic DKI Jakarta. Province of DKI Jakarta 2018 Statistics (In Indonesian). Jakarta : BPS DKI Jakarta Province. 2018.
[2] Central Bureau of Statistic DKI Jakarta. DKI Jakarta 2018 Transportation Statistic (In Indonesian). Jakarta : BPS DKI Jakarta Province. 2018.

[3] KOMPAS. DTKJ: $30 \%$ of Jakarta Citizen's Income to Ride Public Transportation (In Indonesian). Kompas. [Online]. [Cited: Desember 1 , 2018.] https://megapolitan.kompas.com/read/2017/05/22/16380531/dtkj.30.p ersen.penghasilan.warga.jakarta.untuk.naik.transportasi.umum. 2017.

[4] Abrate, Graziano, Piacenza, Massimiliano and Vannoni, Davide. The Impact of Integrated Tariff System on Public Transport Demand: Evidence from Italy. Heritage Education and Research on Mobility Regulation and The Economics of Local Services. 2007.

[5] SPUTNIC. Public Transport Integration. 6th Framework Programme, European Commission. 2006.

[6] Cassone, Alberto and Marchese, Carla. Welfare Effects of Price Integration in Local Public Transport. Annals of Public and Cooperative Economics 76:2, pp. 257-274. 2005.

[7] Jakarta Transportation. Route Map. TransJakarta (In Indonesian). [Online]. [Cited: Desember 1, 2018.] http://transjakarta.co.id/petarute/. 2017.

[8] MRT' Jakarta. MRT Line Map. MRT Jakarta (In Indonesian). [Online]. [Cited: $\quad$ Desember $1, \quad 18$ 201 https://www.jakartamrt.co.id/peta-jalur-mrt/. 2017.

[9] MRT Jakarta. MRT Jakarta and TransJakarta Plan to Integrate Stations and Stops at Five Points (In Indonesian). [Online]. [Cited: Desember 1, 2018.]. https://www.jakartamrt.co.id/2018/11/29/mrtjakarta-dan-transjakarta-rencanakan-integrasi-stasiun-dan-halte-dilima-titik/. 2018.

[10] Koppelman, Frank S. and Bhat, Chandra. A Self Instructing Course in Mode Choice Modeling: Multinomial and Nested Logit Models. Washington, D.C: Federal Transit Administration. (2006).

[11] Tamin, Ofyzar Z. Transportation Modeling and Engineering Planning : Theory, Example Problems and Applications (In Indonesian). Bandung : Bandung Institute of Technology. 2008.

[12] Kroes, Eric P. and Sheldon, Robert J. Stated Preference Method: An Introduction. Journal of Transport Economics and Policy, Vol.22, No.1, Stated Preference Methods in Transport Research, pp. 11-25. (1988).

[13] Governor of the Jakarta Special Capital Region. The Governor's Regulation of the Jakarta Special Capital Region number 114 of 2018 concerning the Provincial Minimum Wage in 2019 (In Indonesian). Jakarta : s.n.,. 2018. 